\title{
HYDROLOGIC DATA FOR FLOODS OF JULY 1978 IN SOUTHEAST MINNESOTA AND SOUTHWEST WISCONSIN
}

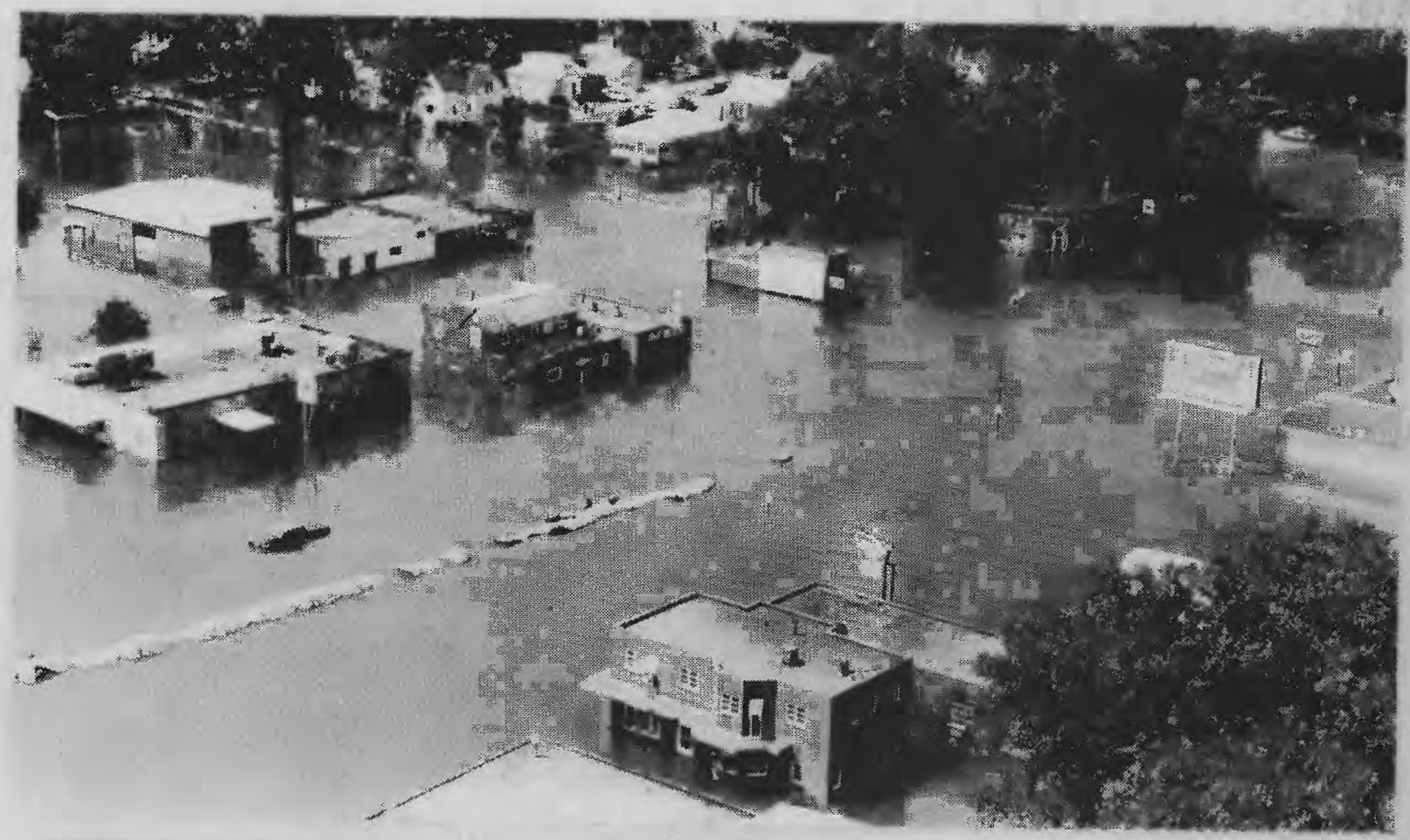

U. S. GEOLOGICAL SURVEY

Open-File Report 79-1166

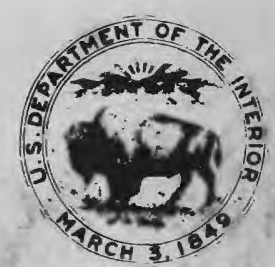


COVER PHOTOGRAPH

East Oakland Avenue and 4 th Street SE, Austin, Minn. was under water by late Monday morning, July 17, 1978. The area, adjacent to the west bank of the Cedar River, was the first in the city to be inundated. (Photograph by courtesy of the Austin Daily Herald.) 
UNITED STATES

DEPARTMENT OF THE INTERIOR

GEOLOGICAL SURVEY

HYDROLOGIC DATA FOR FLOODS OF JULY 1978

IN SOUTHEAST MINNESOTA AND

SOUTHWEST WISCONSIN

By V. J. Latkovich

Open-File Report 79-1166

St. Paul, Minnesota

1979 


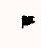

- 


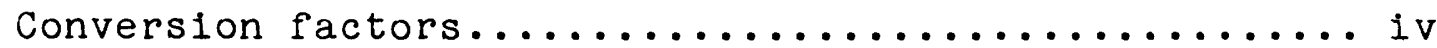

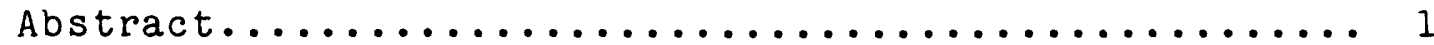

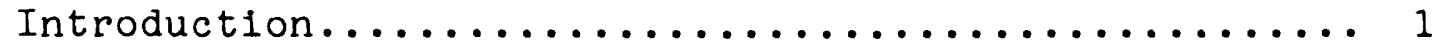

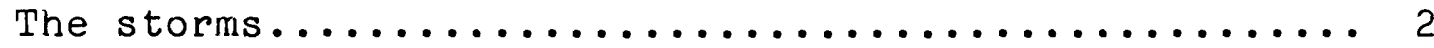

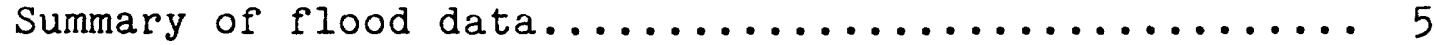

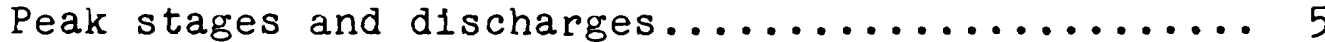

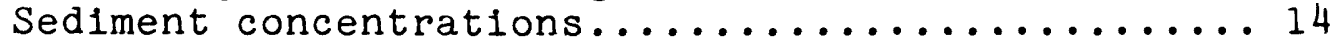

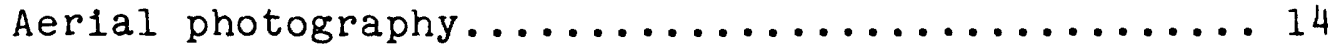

ILLUSTRATIONS

Figure 1. Total storm isohyetal maps for June

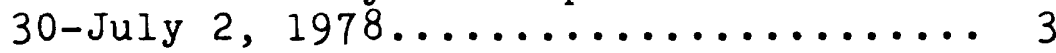

2. Total storm isohyetal maps for July

$5-6,1978$ and July 16-17, 1978....... 4

3. Map showing locations of flood-

measurement stations..............6 6

4. Graph showing comparison of the July

1978 floods with maximum floods

previously determined at the same site. 7

5. Hydrographs of dally mean flow for

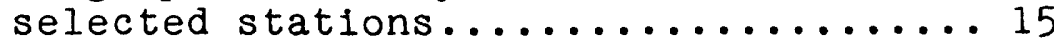

6-10. Photographs of Rochester, Minn.

6. South Fork Zumbro River at sewage-treatment plant....... 16

7. USGS gaging station on the

South Fork Zumbro River...... 17

8. City powerplant along the

South Fork Zumbro River...... 18

9. Shopping center.............. 19

10. Third Avenue $S E$ and the

Beltline................. 20

11. Photograph of Winona County Road 39

bridge over the Whitewater River near

Whitewater State Park, Minn......... 21

12-14. Photographs of Austin, Minn.

12. East Oakland Avenue and $4 \mathrm{th}$

Street SE on the Cedar River.. 22 


\section{ILLUSTRATIONS}

Page

Figures 12-14. Photographs of Austin, Minn.--Continued

13. Cedar River below the $4 \mathrm{th}$

$$
\text { Avenue bridge.............23 }
$$

14. Flooded home in Wildwood

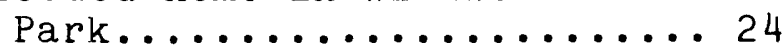

15. Photograph of the Kickapoo River,

Gays Mills, Wis................ 25

16. Photograph of Main Street, Gays

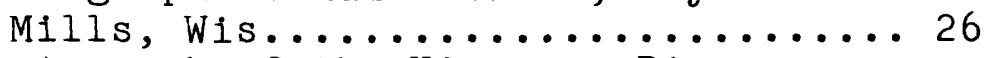

17. Photograph of the Kickapoo River, Soldiers Grove, Wis............. 27

18. Photograph of the Kickapoo River,

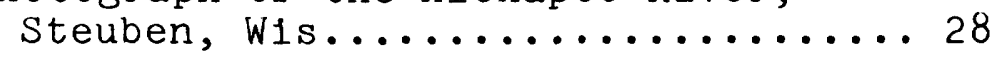

\section{TABLES}

Table 1. Summary of peak stages and discharges for selected sites..................... 8

2. Summary of suspended-sediment data for

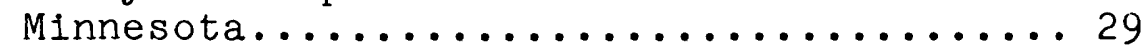

\section{CONVERSION FACTORS}

For the convenience of those readers who prefer to use International System (metric) units rather than inchpound units, the conversion factors for terms used in this report are listed below:

Multiply

inch-pound unit

inch (in)

mile (m1)

square mile $\left(\mathrm{mi}^{2}\right)$

cubic foot per second

$\left(\mathrm{ft}^{3} / \mathrm{s}\right)$

ton (short) per day
By

25.40

1.609

2.590

0.02832

(ms)

millimeter ( $\mathrm{mm}$ )

kilometer (km)

square kilometer $\left(\mathrm{km}^{2}\right)$

cubic meter per second
$\left(\mathrm{m}^{3} / \mathrm{s}\right)$

0.9072 megagram (Mg) 
HYDROLOGIC DATA FOR FLOODS OF JULY 1978

IN SOUTHEAST MINNESOTA AND

SOUTHWEST WISCONSIN

By V. J. Latkovich

\section{ABSTRACT}

Intense storms of July 1978 caused floods of historical significance in southeast Minnesota and southwest Wisconsin. Local, State, and Federal of ficials need data and information to evaluate, coordinate, and manage programs concerned with floods and flood losses. Because of a need to document stream discharges, elevations, and sediment concentrations, currentmeter and indirect measurements were made at 34 gaging stations during or immediately after the floods. This report summarizes some of the hydrologic data collected. Peak discharges of record occurred at 20 gaging stations. Frequency of peak discharge equaled or exceeded the 100-year recurrence interval at 11 stations. The Federal Benchmark gaging station on the North Fork Whitewater River was destroyed. Five people died as a result of the floods, and property damages were estimated to exceed $\$ 114$ million. Thirty-three counties were officially declared disaster areas.

\section{INTRODUCTION}

Intense storms of July 1978 , combined with wet antecedent soil-moisture conditions of late June, caused floods of historical significance in the South Fork Zumbro, Whitewater, and Cedar River basins of southeast Minnesota, and the Kickapoo River basin of southwest Wisconsin. Five people died as a result of the floods, and total property damages were estimated by the States of Minnesota and Wisconsin to exceed $\$ 114$ million. Thirty-three counties were officially declared disaster areas. The Federal Benchmark gaging station on the North Fork Whitewater River near Elba, Minn., was destroyed by floodwaters that devastated the Whitewater State Park and Wildlife Area.

Local, State, and Federal officials need data and information to evaluate, coordinate, and manage programs concerned with floods and flood losses. The purpose of this report is to provide a summary of some of the hydrologic data collected during the July 1978 floods. Only a part of the information collected by the U.S. Geological Survey on the extent and 
magnitude of the floods is presented. This information includes the magnitude and frequency of the instantaneous maximum stages (water-surface elevations) and discharges for 34 gaging stations, measured suspended-sediment loads at 4 stations, and hydrographs of daily mean discharge at 5 sites. Additional stream discharge information associated with the floods will be published in annual data releases of the Geological Survey. Photographic data depicting the areal extent of flooding can be viewed at the Geological Survey's Minnesota District Office in St. Paul.

Storm chronologies and rainfall data are summarized in this report to aid in documenting the floods. These data were provided by the Minnesota Department of Natural Resources (DNR), State office of Climatology, and the Wisconsin Department of Natural Resources. The isohyetal maps ( $f$ igs. 1 and 2) were provided by the Minnesota DNR and the Wisconsin DNR. Their assistance in providing the data is greatly appreciated.

\section{THE STORMS}

The following accounts of the storms were provided by the Minnesota DNR, State Office of Climatology:

"Eastern and southeastern Minnesota experienced widespread flash flooding on June 30 and July 1, 1978. These floods differed from the usual flash flood pattern. A typical pattern has only one localized area of high-intensity precipitation, generally from a single cell. Seven to nine separate areas in eastern and southeastern Minnesota had over 6 inches of precipitation on June 30-July 1 from several storm cells forming during a 14-hour period. Numerous heavy thunderstorms moved east to southeast from a 140-mile-long line extending from western Ramsey County (the Twin Cities) to western Houston County ( 25 miles west of the Iowa-MinnesotaWisconsin border). Portions of Wabasha, Olmsted, Winona, Fillmore, and Houston Counties received over 6 inches of precipitation. A 6 or more inch rainfall is a 100-year or greater storm for this area. Greater than 8 inches of precipitation was reported in Mount Pleasant and Highland Townships in Wabasha county and in Arendahl and Rushford Townships in Fillmore County. The largest recorded amount was 8.68 inches. A 2,850 square mile area received greater than 4 inches of precipitation in Minnesota. Generally, the heaviest and most extensive rainfalls were across Wabasha, Winona, and Houston Counties." 


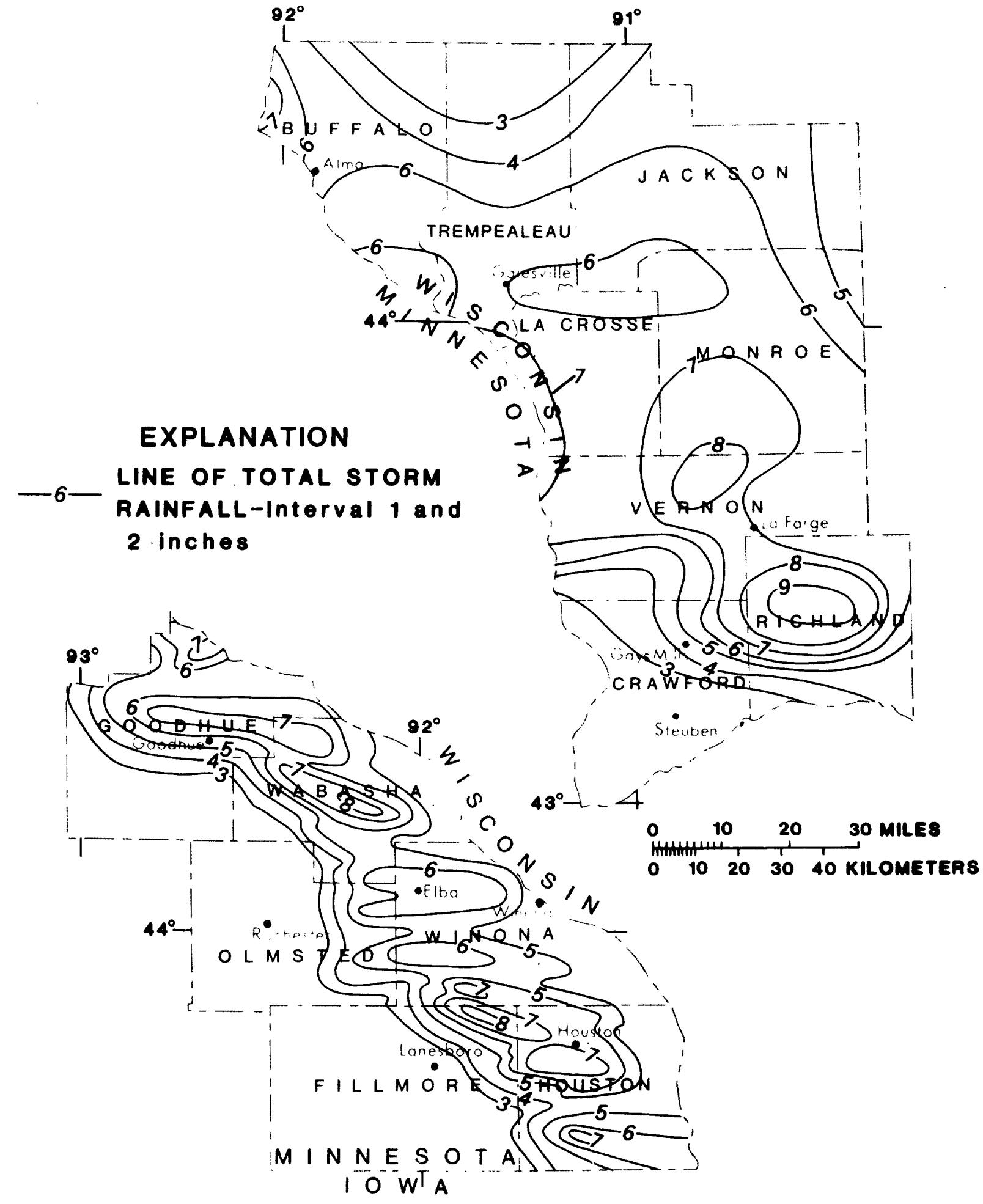

Figure 1.--Total storm isohyetal maps for June 30-July 2, 1978 


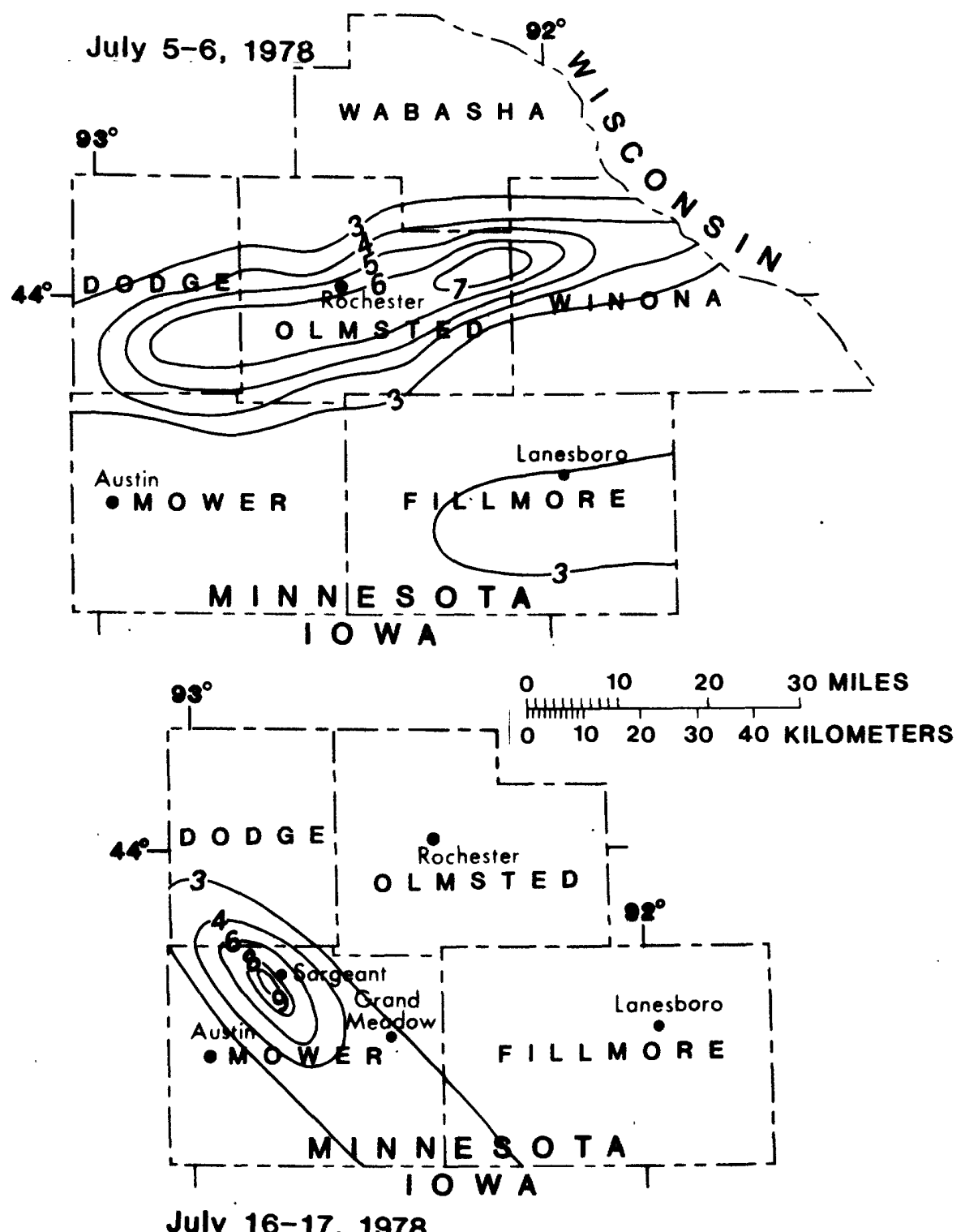

July 16-17, 1978

\section{EXPLANATION}

LINE OF TOTAL STORM

-3- RAINFALL-Interval 1 and

2 inches

Figure 2.--Total storm isohyetal maps for Juil 5-6, 1978 and July 16-17, 1978 


\begin{abstract}
"The flash flood for Rochester, Minn. occurred from heavy rains of 6 inches or more. The storm began at Rochester alrport at 05:35 P.M. CDST on July 5, 1978 and ended at 01:50 A.M. CDST on July 6, 1978. The National Weather Service weighing rain gage recorded in a 3-hour period (05:53 P.M. CDST to 08:53 P.M. CDST) 4.99 inches of rain, which is well above the 100-year return period. The heaviest amount, 7.30 inches, occurred in Quincy Township in eastern OImsted County. The 4-inch or more rainfall band was about 12-15 miles wide and 75 miles $10 \mathrm{ng}$ and covered an area of 700 square miles. The line oriented eastnortheast began 25 miles west-southwest of Rochester and ended 50 miles east on the Minnesota-Wisconsin border."
\end{abstract}

"The flash flood at Austin, Minn. occurred from heavy rains of 8 inches or more. The rain began at approximately 9:00 P.M. CDST on July 16 and ended during the early morning hours of July 17 . This was the second flash flood to occur in the headwaters of the Cedar River, north of Austin, in 11 days. Both floods resulted in record breaking flood levels at Austin. The largest amount of rain reported was 9.50 inches in Watham Township ( 2 miles southwest of Sargeant) in northwestern Mower County. The 4-inch or greater rainfalls were oriented northwest to southeast and covered an area of 160 square miles."

\title{
SUMMARY OF FLOOD DATA
}

\section{Peak Stages and Discharges}

Peak stages and discharges were obtained and documented by current-meter and indirect measurement methods at 34 gaging stations in Minnesota and Wisconsin. Locations of the stations are shown in figure 3 .

A summary of the peak stages and discharges at 16 continuous-record and 18 crest-stage partial-record stations (fig. 3) is presented in table 1. Data presented are for both the maximum flood previously known and the maximum during the July 1978 floods. The relative magnitude of the 1978 floods compared with that of previous floods is shown in

figure 4. Perlods of record range from 9 to 70 years. At 20 stations the 1978 floods exceeded the previous maximums. At 11 of the 20 stations, maximums equaled or exceeded the 100year recurrence interval. The recurrence interval is the average interval of time within which a given flood will be exceeded once; that is, a flood expected to be equaled or 


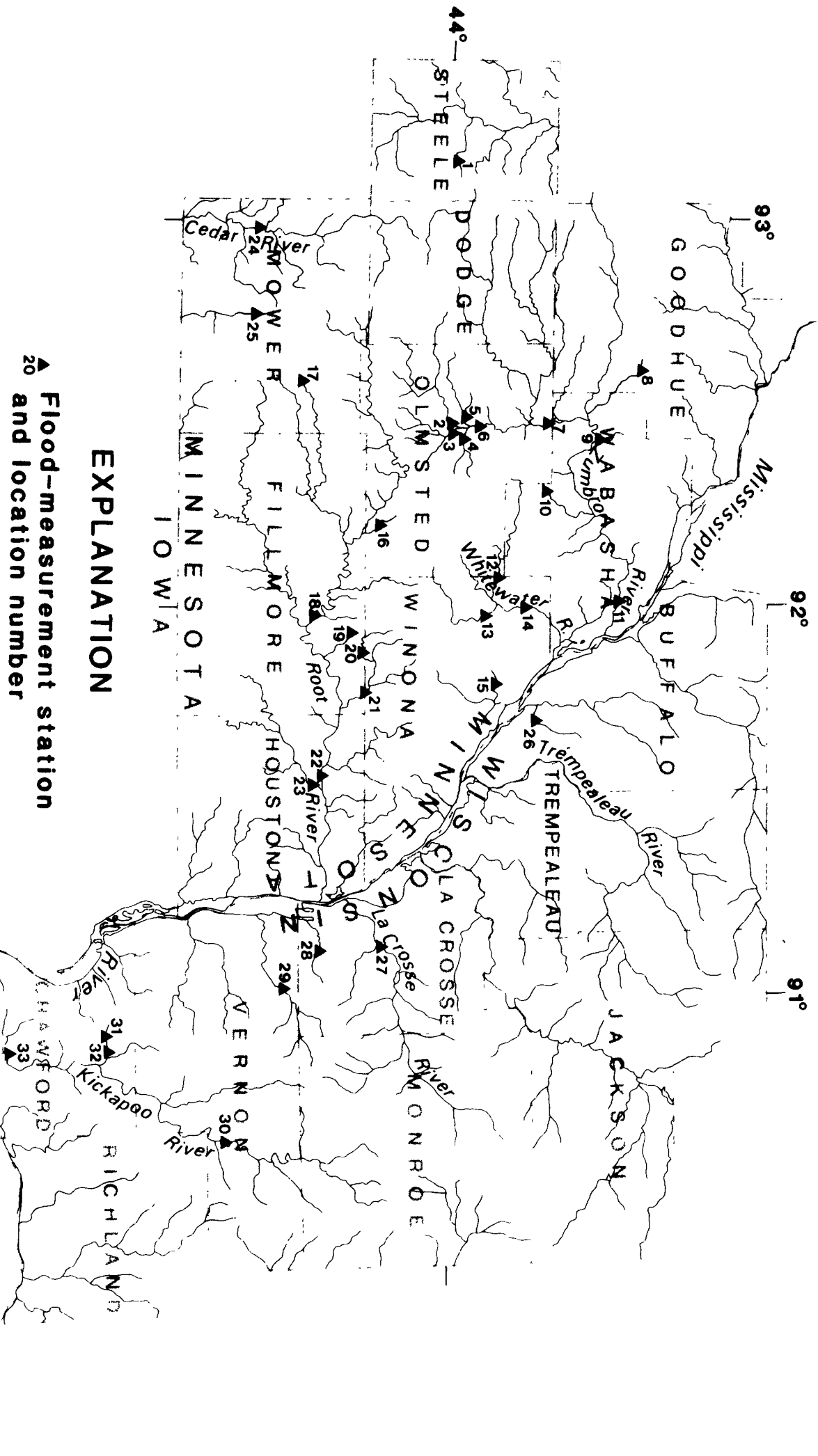




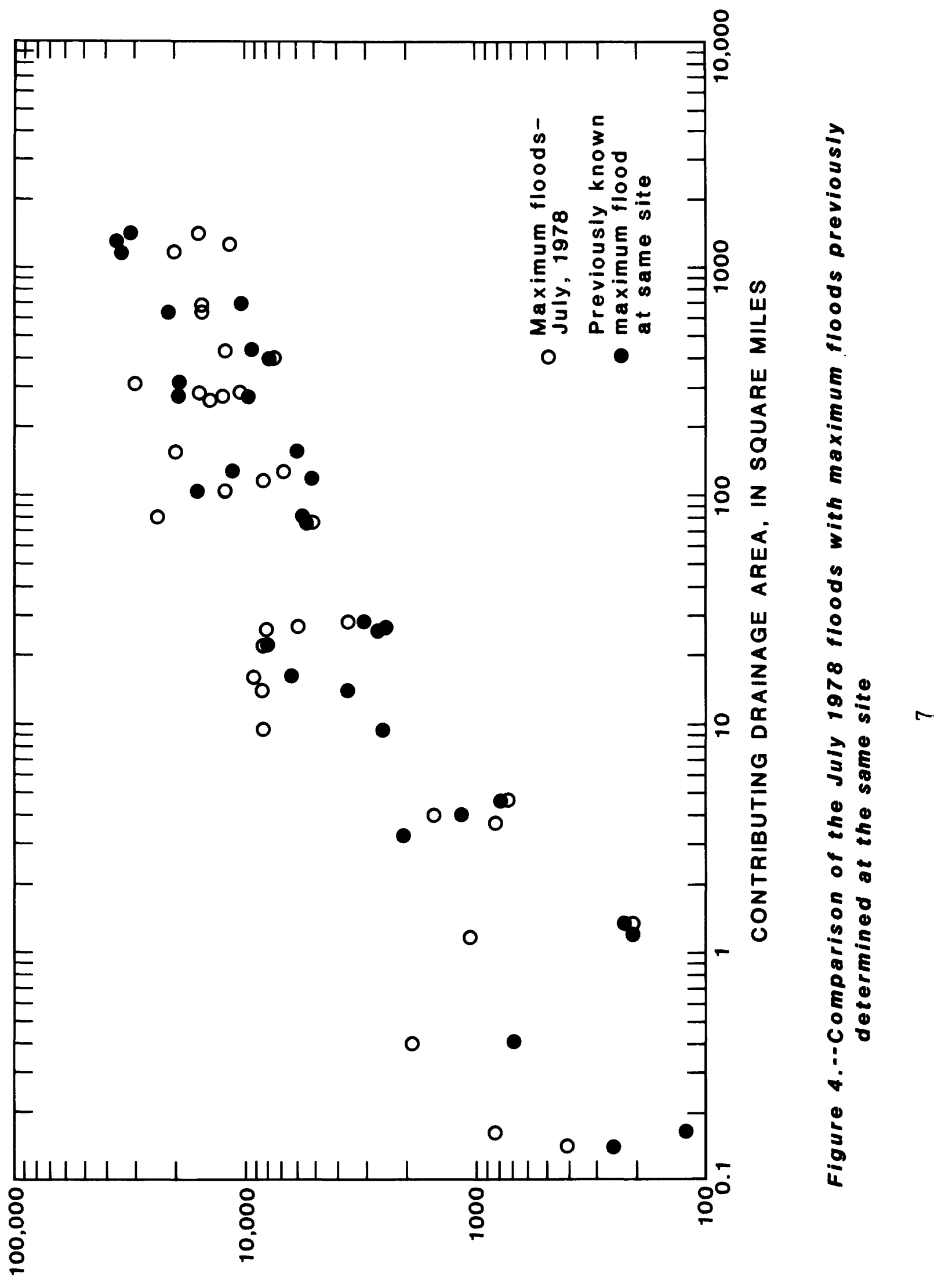


Table 1.--Summary of peak stages and

$[+=$ number for location purpose in = greater than; * = peak discharge measurement (affected by backwater approximately; $<=$ less than; $a=$ measurement.]

\begin{tabular}{|c|c|c|c|c|}
\hline+ No. & $\begin{array}{l}\text { WRD } \\
\text { station } \\
\text { number }\end{array}$ & $\begin{array}{c}\text { Stream and place of } \\
\text { determination }\end{array}$ & $\begin{array}{l}\text { Drainage } \\
\text { area } \\
\left(\mathrm{mi}^{2}\right) \\
\end{array}$ & $\begin{array}{l}\text { Period of } \\
\text { known floods } \\
\end{array}$ \\
\hline 1 & 05252700 & 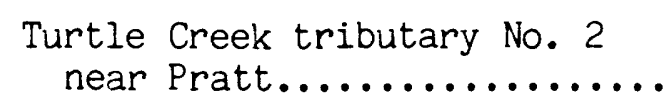 & 1.26 & $1960-78$ \\
\hline 2 & 05372800 & $\begin{array}{l}\text { South Fork Zumbro River on } \\
\text { Beltline at Rochester........ }\end{array}$ & 155 & $1969-78$ \\
\hline 3 & 05372930 & 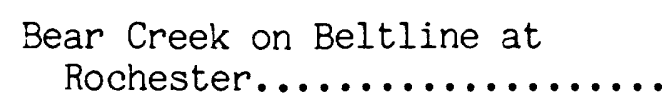 & 80.0 & $1959-78$ \\
\hline 4 & 05372950 & Silver Creek at Rochester...... & 17.3 & $1969-78$ \\
\hline 5 & 05372990 & Cascade Creek at Rochester..... & 37 & $1969-78$ \\
\hline 6 & 05373000 & 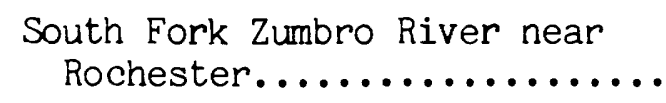 & 304 & $\begin{array}{l}1855 \\
1908-78\end{array}$ \\
\hline 7 & 05373350 & $\begin{array}{l}\text { Zumbro River tributary near } \\
\text { South Troy................. }\end{array}$ & 0.16 & $1962-78$ \\
\hline 8 & 05373900 & 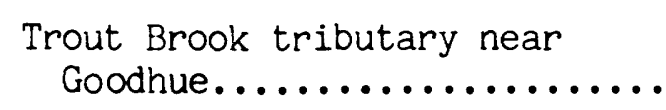 & 0.40 & $1960-78$ \\
\hline 9 & 05374000 & Zumbro River at Zumbro Falls... & 1130 & $\begin{array}{l}1909-17 \\
1930-78\end{array}$ \\
\hline 10 & 05374400 & Long Creek near Potsdam........ & 4.46 & $1966-78$ \\
\hline 11 & 05374900 & Zumbro River at Kellogg........ & 1400 & $1938-78$ \\
\hline 12 & 05376000 & $\begin{array}{l}\text { North Fork Whitewater River } \\
\text { near Elba................. }\end{array}$ & 101 & $1939-78$ \\
\hline
\end{tabular}


discharges for selected stations

this report only, see figure $3 ;>$ estimated based on current-meter from South Fork Zumbro River); = provisional record; $b=$ discharge

Maximum flood previously
known

Maximum during present flood

Recurrence Date Stage Discharge interval (ft) $(\mathrm{ft} 3 / \mathrm{s})$

$/ \mathrm{mi}^{2}$

MINNESOTA

\begin{tabular}{|c|c|c|c|c|c|c|c|c|}
\hline $5-31-61$ & 19.79 & 220 & July & 17 & 20.48 & 211 & 167 & 15 \\
\hline $3-10-73$ & 1001.78 & 6,020 & July & 6 & 1005.97 & 20,500 & 132 & $>100$ \\
\hline $6-21-74$ & 1003.39 & 5,800 & July & 6 & 1007.87 & 24,900 & 311 & $>100$ \\
\hline $6-21-74$ & 1015.65 & 6,580 & July & 6 & 1016.18 & 9,290 & 537 & $>100$ \\
\hline $6-21-74$ & 983.52 & 2,050 & July & 6 & 986.21 & $*_{1}^{*}, 000$ & --- & --- \\
\hline $3-1-65$ & 19.12 & 19,600 & July & 6 & 23.36 & 30,500 & 100 & $>100$ \\
\hline $6-20-74$ & 12.72 & 122 & July & 7 & 14.07 & 138 & 862 & 25 \\
\hline $5-28-70$ & 13.84 & 592 & July & 1 & 13.98 & 759 & 1,900 & 100 \\
\hline $7-22-51$ & 30.80 & 35,900 & $\begin{array}{l}\text { July } \\
\text { July }\end{array}$ & $\begin{array}{l}7 \\
1\end{array}$ & $\begin{array}{l}24.26 \\
15.53\end{array}$ & $\begin{array}{r}20,800 \\
7,800\end{array}$ & $\begin{array}{r}18.4 \\
6.9\end{array}$ & 8 \\
\hline $6-20-74$ & 26.50 & 773 & July & 17 & 22.10 & 574 & 129 & 15 \\
\hline $7-22-51$ & --- & $\begin{array}{c}\text { May have } \\
\text { exceeded } \\
30,000\end{array}$ & $\begin{array}{l}\text { July } \\
\text { July }\end{array}$ & $\begin{array}{l}2 \\
8\end{array}$ & $\begin{array}{l}12.70 \\
13.70\end{array}$ & $\begin{array}{l}14,400 \\
16,800\end{array}$ & $\begin{array}{l}10.3 \\
12.0\end{array}$ & -- \\
\hline $6-21-74$ & 16.32 & 16,100 & $\begin{array}{l}\text { July } \\
\text { July }\end{array}$ & $\begin{array}{l}1 \\
5\end{array}$ & $\begin{array}{l}10.27 \\
15.57\end{array}$ & $\begin{array}{r}4,720 \\
12,800\end{array}$ & $\begin{array}{c}46.7 \\
127\end{array}$ & 22 \\
\hline
\end{tabular}


Table 1.--Summary of peak stages and dis

\begin{tabular}{|c|c|c|c|c|}
\hline+ No. & $\begin{array}{c}\text { WRD } \\
\text { station } \\
\text { number } \\
\end{array}$ & $\begin{array}{c}\text { Stream and place of } \\
\text { determination }\end{array}$ & $\begin{array}{c}\text { Drainage } \\
\text { area } \\
\left(m i^{2}\right)\end{array}$ & $\begin{array}{l}\text { Period of } \\
\text { known floods }\end{array}$ \\
\hline 13 & 05376500 & $\begin{array}{l}\text { South Fork Whitewater River } \\
\text { near Altura............... }\end{array}$ & 76.8 & $1939-78$ \\
\hline 14 & 05376800 & Whitewater River near Beaver... & 271 & $1939-78$ \\
\hline 15 & 05378300 & $\begin{array}{l}\text { Straight Valley Creek near } \\
\quad \text { Rollingstone............... }\end{array}$ & 5.16 & $1959-78$ \\
\hline 16 & 05383720 & Mill Creek near Chatfield...... & 22.4 & $1962-78$ \\
\hline 17 & 05383850 & $\begin{array}{l}\text { South Fork Bear Creek near } \\
\text { Grand Meadow............... }\end{array}$ & 14.0 & $1962-78$ \\
\hline 18 & 05384000 & Root River near Lanesboro....... & 615 & $\begin{array}{l}1910-17 \\
1940-78\end{array}$ \\
\hline 19 & 05384300 & Big Springs Creek near Arendahl & 0.14 & $1959-78$ \\
\hline 20 & 05384400 & Pine Creek near Arendahl....... & 28.1 & $1959-78$ \\
\hline 21 & 05384500 & Rush Creek near Rushford....... & 129 & $1942-78$ \\
\hline 22 & 05385000 & Root River near Houston........ & 1270 & $\begin{array}{l}1907-17 \\
1930-78\end{array}$ \\
\hline 23 & 05385500 & 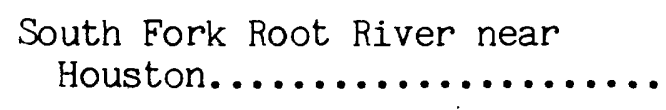 & 275 & $1953-78$ \\
\hline 24 & 05457000 & Cedar River near Austin........ & 425 & $\begin{array}{l}1909-14 \\
1944-78\end{array}$ \\
\hline 25 & 05457080 & Rose Creek tributary........... & 1.17 & $1962-78$ \\
\hline
\end{tabular}


charges for selected stations--Continued

\begin{tabular}{|c|c|c|c|c|c|c|c|}
\hline \multirow[t]{2}{*}{ Maximum } & \multicolumn{2}{|c|}{$\begin{array}{l}\text { flood previously } \\
\text { known }\end{array}$} & \multicolumn{4}{|c|}{ Maximum during present flood } & \multirow{2}{*}{$\begin{array}{l}\text { Recur- } \\
\text { rence } \\
\text { interval } \\
\text { (years) }\end{array}$} \\
\hline & $\begin{array}{l}\text { Stage } \\
(\mathrm{ft})\end{array}$ & $\begin{array}{c}\text { Discharge } \\
\left(\mathrm{ft}^{3} / \mathrm{s}\right)\end{array}$ & Date & $\begin{array}{c}\text { Stage } \\
(\mathrm{ft})\end{array}$ & $\begin{array}{l}\text { Dische } \\
\left(\mathrm{ft}^{3} / \mathrm{s}\right)\end{array}$ & $\begin{array}{l}\operatorname{argeg} \\
\left(\mathrm{ft}^{3} / \mathrm{s}\right)\end{array}$ & \\
\hline $6-21-74$ & 10.84 & 5,620 & $\begin{array}{ll}\text { July } & 1 \\
\text { July } & 5\end{array}$ & $\begin{array}{r}8.55 \\
10.83\end{array}$ & $\begin{array}{l}3,440 \\
5,610\end{array}$ & $\begin{array}{l}44.8 \\
73.0\end{array}$ & 25 \\
\hline $6-21-74$ & 13.00 & 19,200 & $\begin{array}{l}\text { July } 1 \\
\text { July } 6\end{array}$ & $\begin{array}{l}12.09 \\
12.88\end{array}$ & $\begin{array}{l}10,300 \\
15,400\end{array}$ & $\begin{array}{l}38.0 \\
56.8\end{array}$ & 30 \\
\hline $6-26-59$ & 17.28 & 1,200 & $\begin{array}{ll}\text { July } & 1 \\
\text { July } & 5\end{array}$ & $\begin{array}{l}17.04 \\
18.10\end{array}$ & $\begin{array}{l}1,110 \\
1,500\end{array}$ & $\begin{array}{l}215 \\
291\end{array}$ & 40 \\
\hline $6-21-74$ & 17.51 & 7,900 & July 6 & 17.68 & 8,580 & 383 & 75 \\
\hline $3-28-62$ & 21.18 & 3,730 & July 17 & 23.18 & 8,500 & 607 & $>100$ \\
\hline $3-29-62$ & 16.11 & 22,100 & $\begin{array}{lr}\text { July } & 1 \\
\text { July } & 7 \\
\text { July } & 18\end{array}$ & $\begin{array}{l}10.16 \\
15.41 \\
13.25\end{array}$ & $\begin{array}{r}6,700 \\
14,400 \\
10,900\end{array}$ & $\begin{array}{l}10.9 \\
23.4 \\
17.7\end{array}$ & 4 \\
\hline $6-20-74$ & 11.61 & 256 & July 1 & 11.09 & 56.7 & 405 & 8 \\
\hline $6-21-74$ & 14.85 & 3,100 & July. 1 & 15.58 & 4,150 & 134 & 40 \\
\hline $3-26-50$ & 13.54 & 11,600 & July 1 & 11.20 & 7,930 & 61.5 & 7 \\
\hline $4-11-52$ & 13.90 & 37,000 & $\begin{array}{ll}\text { July } & 1 \\
\text { July } & 8\end{array}$ & $\begin{array}{l}12.20 \\
11.97\end{array}$ & $\begin{array}{l}12,200 \\
11,800\end{array}$ & $\begin{array}{l}9.6 \\
9.3\end{array}$ & 2.5 \\
\hline $6-21-74$ & 13.81 & 11,000 & $\begin{array}{ll}\text { July } & 1 \\
\text { July } & 6\end{array}$ & $\begin{array}{l}13.79 \\
13.62\end{array}$ & $\begin{array}{l}11,000 \\
10,200\end{array}$ & $\begin{array}{l}40.0 \\
37.1\end{array}$ & 33 \\
\hline $3-29-62$ & 17.18 & 9,530 & $\begin{array}{lr}\text { July } & 7 \\
\text { July } & 17\end{array}$ & $\begin{array}{l}18.06 \\
20.35\end{array}$ & $\begin{array}{l}10,100 \\
12,400\end{array}$ & $\begin{array}{l}24.0 \\
29.2\end{array}$ & 25 \\
\hline $7-9-65$ & 10.31 & 201 & July 17 & 11.82 & 1,090 & 932 & $>100$ \\
\hline
\end{tabular}


Table 1.--Summary of peak stages and dis

\begin{tabular}{|c|c|c|c|c|}
\hline+ No & $\begin{array}{l}\text { WRD } \\
\text { station } \\
\text { number }\end{array}$ & $\begin{array}{l}\text { Stream and place of } \\
\text { determination }\end{array}$ & $\begin{array}{c}\text { Drainage } \\
\text { area } \\
\left(m i^{2}\right)\end{array}$ & $\begin{array}{c}\text { Period of } \\
\text { known floods }\end{array}$ \\
\hline
\end{tabular}

$2605378200 \quad$ Eagle Creek near Fountain City. $26.8 \quad$ 1961-78

$2705283000 \quad$ LaCrosse River near West Salem. $398 \quad$ 1913-70

$2805386300 \quad$ Mormon Creek near LaCrosse..... $25.5 \quad$ 1961-78

$2905387000 \quad$ Coon Creek near Stoddard...... $119 \quad$ 1934-40

$3005408000 \quad$ Kickapoo River at LaFarge..... $266 \quad$ 1938-78

$3105409870 \quad$ Nederlo Creek at Utica Town

Hall near Gays Mills........ $6.7 \quad$--

$3205409890 \quad$ Nederlo Creek near Gays Mills.. $9.46 \quad$ 1967-78

$3305410500 \quad$ Kickapoo River at Steuben..... $690 \quad$ 1933-78

$3405410700 \quad$ Kickapoo River at Wauseka..... 768 
charges for selected stations--Continued

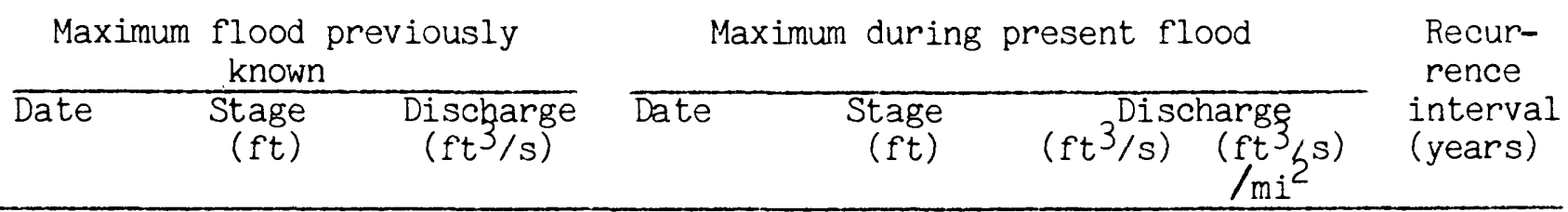

WISCONSIN

\begin{tabular}{|c|c|c|c|c|c|c|c|}
\hline $8-20-68$ & 17.11 & 2,460 & July & 7 & 18.35 & 6,000 & 224 \\
\hline $8-6-35$ & 12.2 & 8,200 & July & 2 & 12.82 & 7,600 & 19.1 \\
\hline $8-3-77$ & 15.48 & 2,640 & July & 2 & 20.60 & 8,140 & 319 \\
\hline $8-6-35$ & 10.70 & 5,160 & July & 2 & 662.53 & 7,900 & 73.9 \\
\hline $2-9-66$ & 13.67 & 9,910 & July & 1 & 14.92 & 14,300 & 53.8 \\
\hline-- & --- & -- & July & 1 & 17.6 & $a 5,700$ & a851 \\
\hline $6-23-68$ & 17.06 & 2,600 & June & 30 & 18.65 & $a 8,500$ & a899 \\
\hline $3-28-61$ & 12.33 & 10,800 & July & 3 & 14.81 & a15,500 & a22. 5 \\
\hline-- & -- & -- & July & 3 & -- & b18,300 & 23.8 \\
\hline
\end{tabular}


exceeded once every 100 years on the average. The U.S. Army Corps of Engineers estimated the flood stage and discharge for Bear Creek at Rochester, Minn., to approximate the 500year recurrence interval. The duration of flooding was 2 to 3 days as shown in figure 5. Figures 6-18 are a series of photographs taken by Geological Survey and local newspaper photographers during and after the floods.

\section{Sediment Concentrations}

Suspended-sediment data were collected at four stations in Minnesota during the floods. A summary of the data is presented in table 2 .

\section{Aerial Photography}

The Geological Survey, through a contractor, obtained contracted aerial photographs of the flooding in and around Rochester on July 6. The photographs were taken from an altitude of 1,800 feet, producing a photo scale of 1 inch = 300 feet. Time of the photography coincided with the peak stage and discharge of the South Fork Zumbro River.

Photographs include:

1. South Fork Zumbro River--from 5 miles south to 5 miles north of Rochester.

2. Bear Creek--from 5 miles east to South Fork Zumbro River.

3. Cascade Creek--from 4 miles west to South Fork Zumbro river.

4. Silver Creek--from 2 miles east to South Fork Zumbro river.

The photographs can be viewed at the Geological Survey District office in St. Paul.

The Wisconsin Department of Natural Resources obtained aerial photographs of flooding in the Kickapoo River basin; they can be viewed at the WDNR Madison office. 


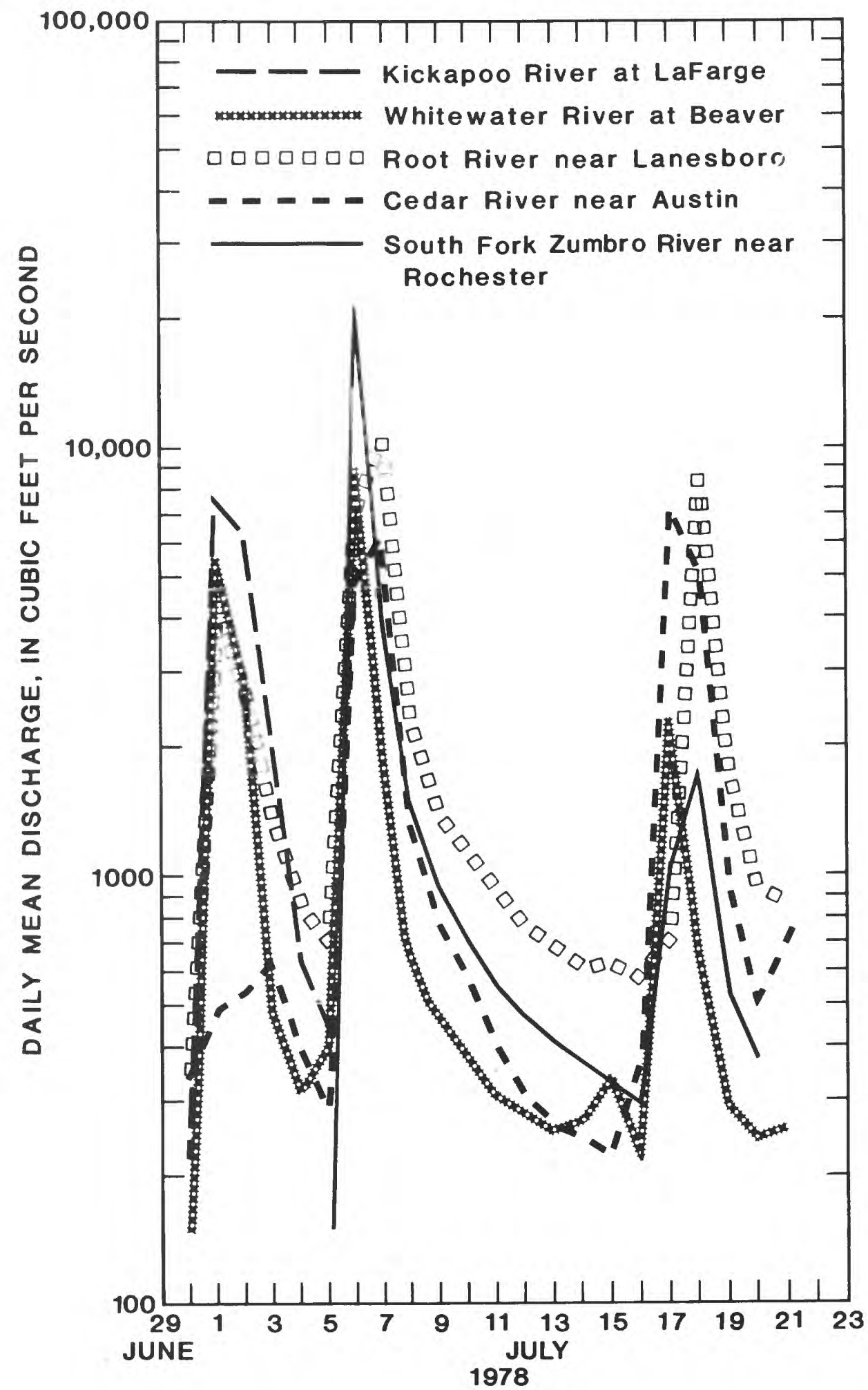

Figure 5.--Hydrographs of daily mean flow for selected stations 


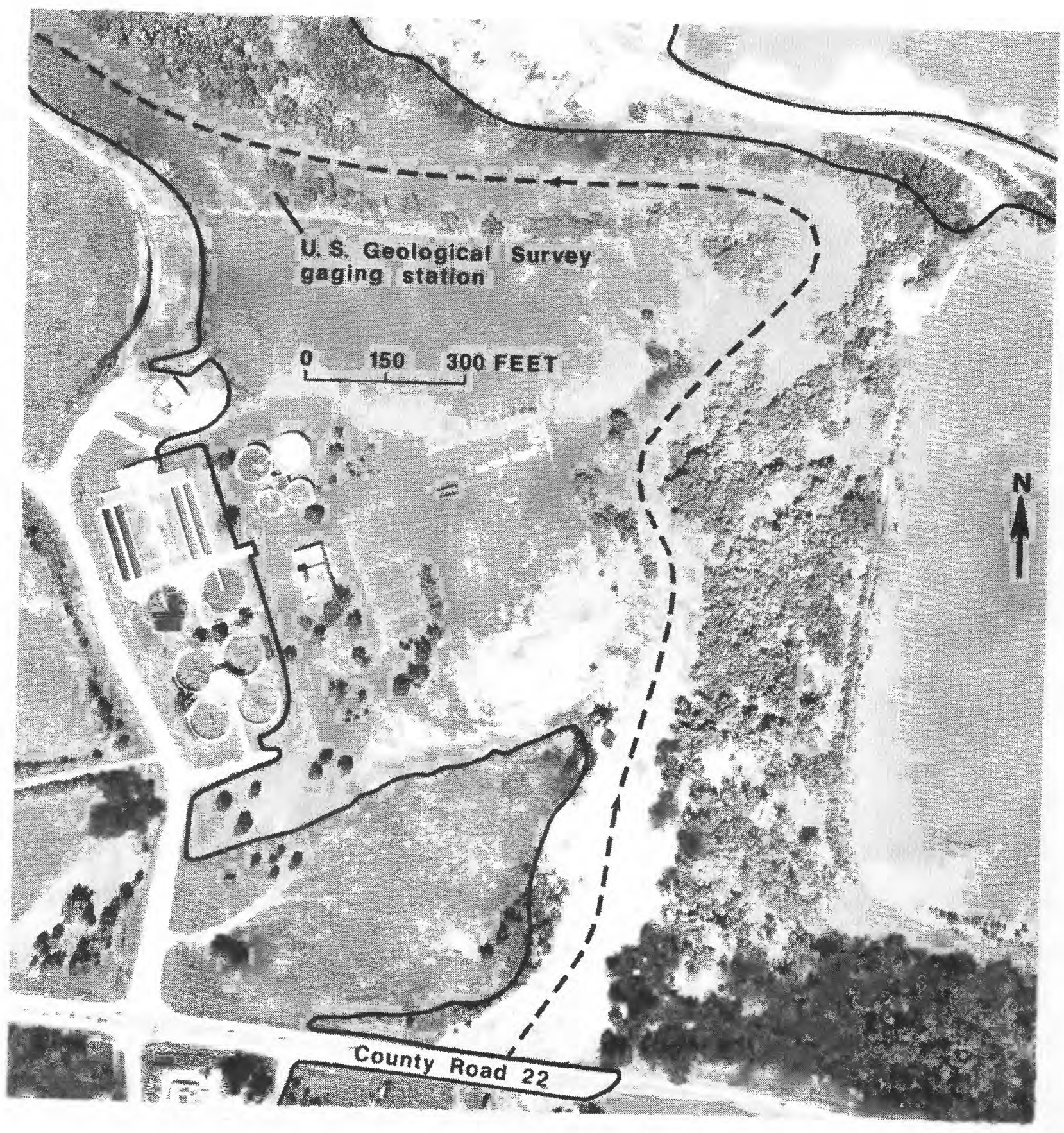

Figure 6.--South Fork Zumbro River at the Rochester Minn. Sewagetreatment plant and $U$. S. Geological Survey gaging station. at the crest elevation (flow did breach County Road 22 ). Continuous line approximates the lateral extent of flooding Dashed line approximates the low-flow channel of the river. Photograph taken about noon on July 6,1978 by Mark Hurd Aerial Surveys, Inc., Minneapolis, Minn. 

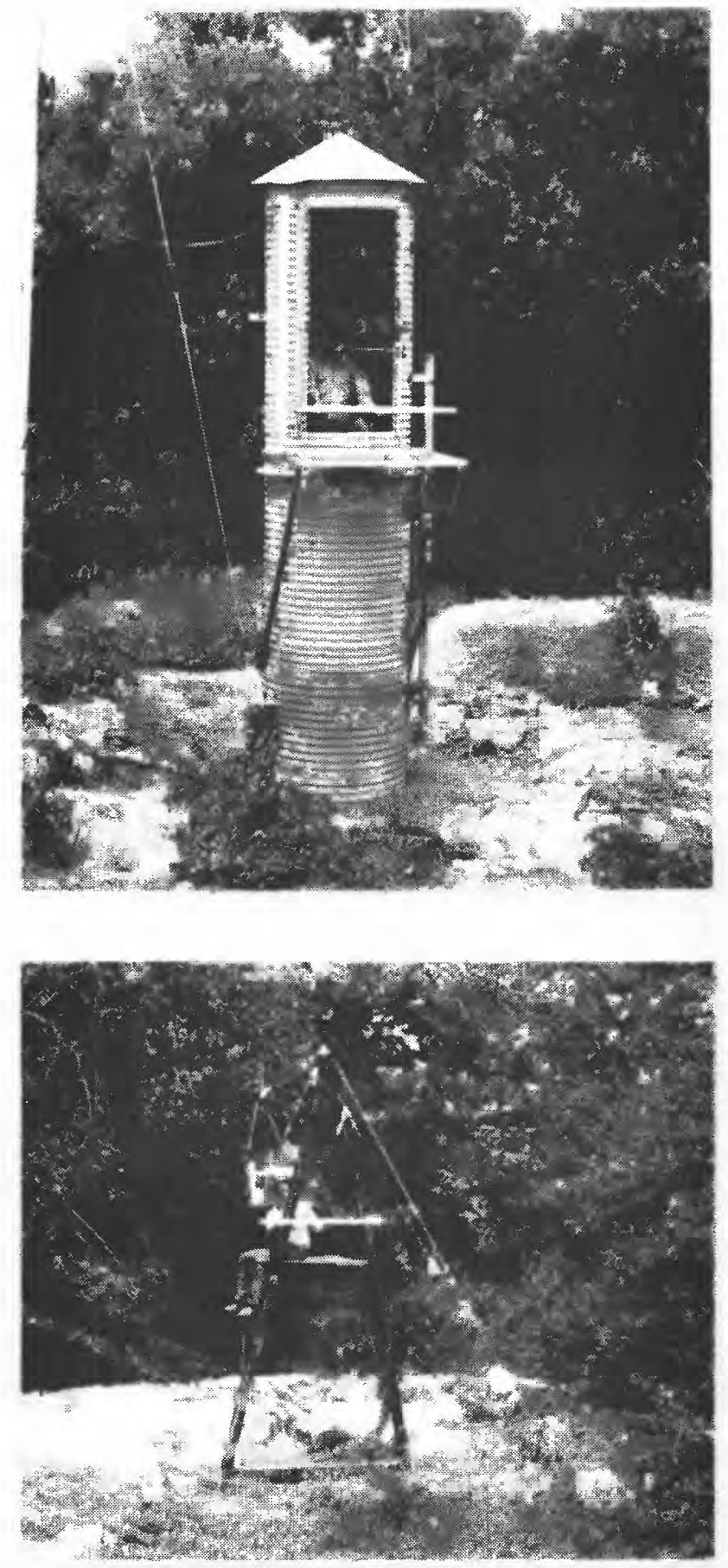

Figure 7.--U.S. Geological Survey gaging station on the South Fork Zumbro River near Rochester, Minn. (below the sewage treatment plant). Horizontal rod is at the July 6, 1978, crest elevation of the river at the instrument shelter and cableway. 


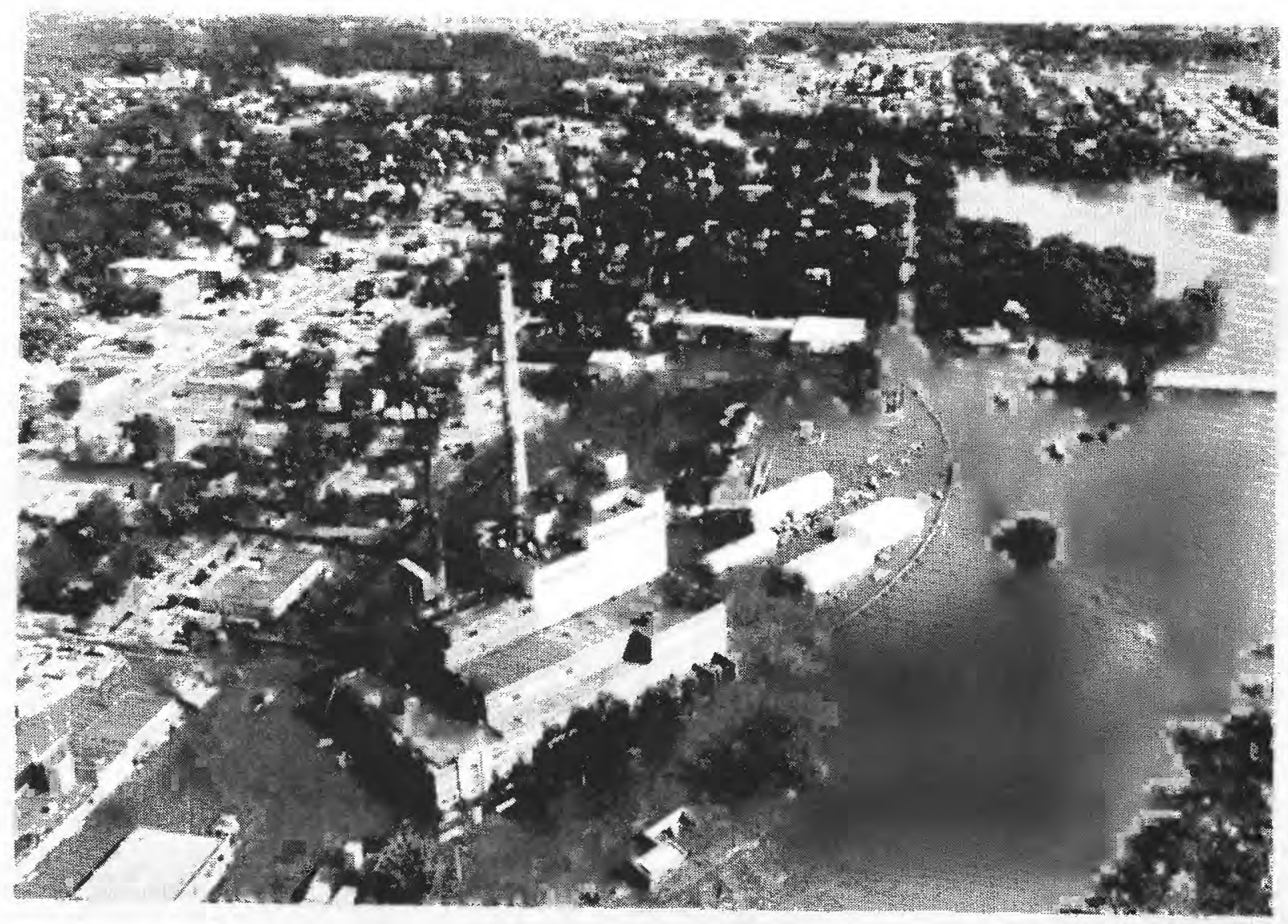

Figure 8.--City power plant on the South Fork Zumbro River, Rochester, Minn. (Rochester Post-Bulletin, July 6, 1978) 


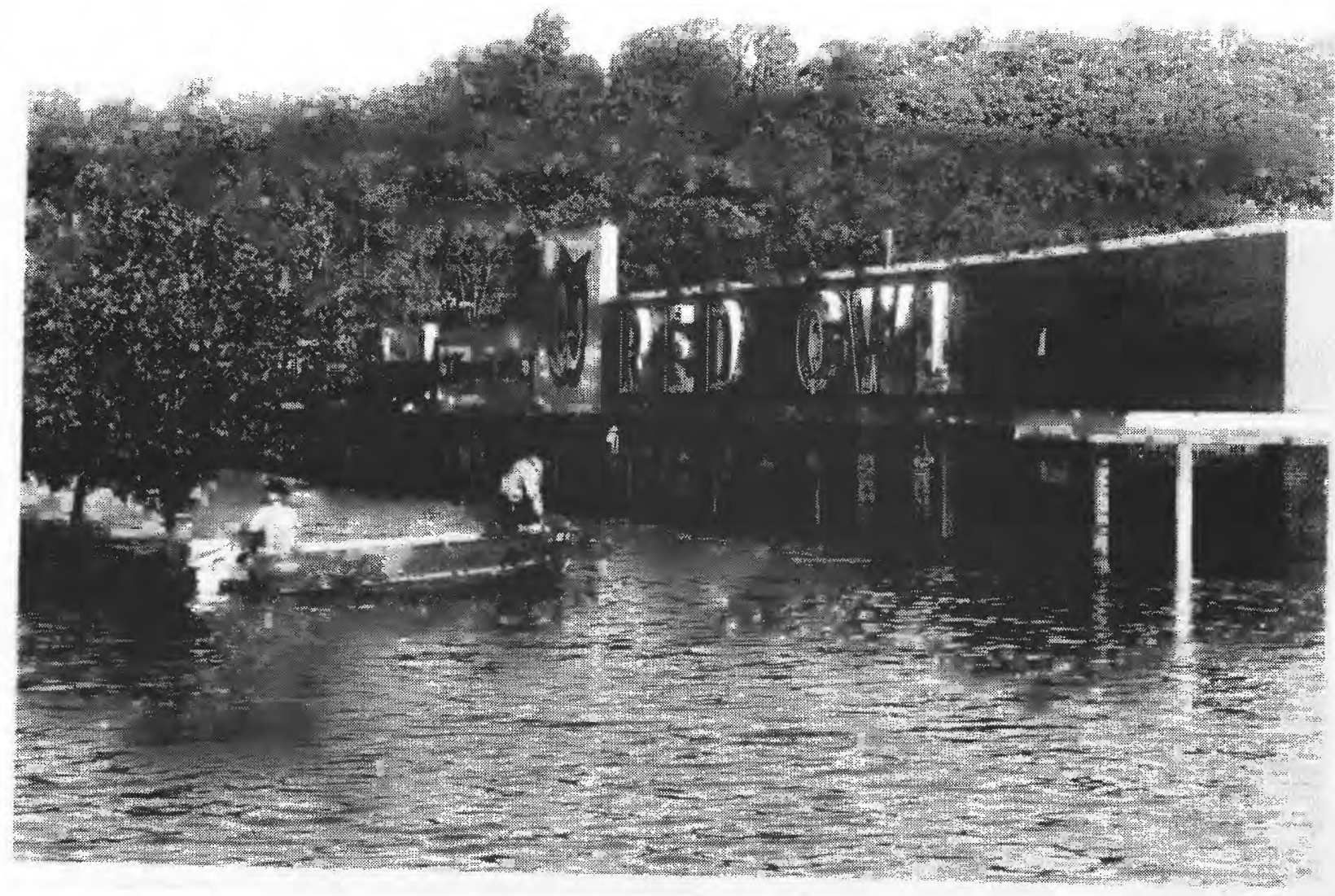

Figure 9.--Shopping center, Rochester, Minn. (Rochester Post-Builetin, July 6, 1978) 


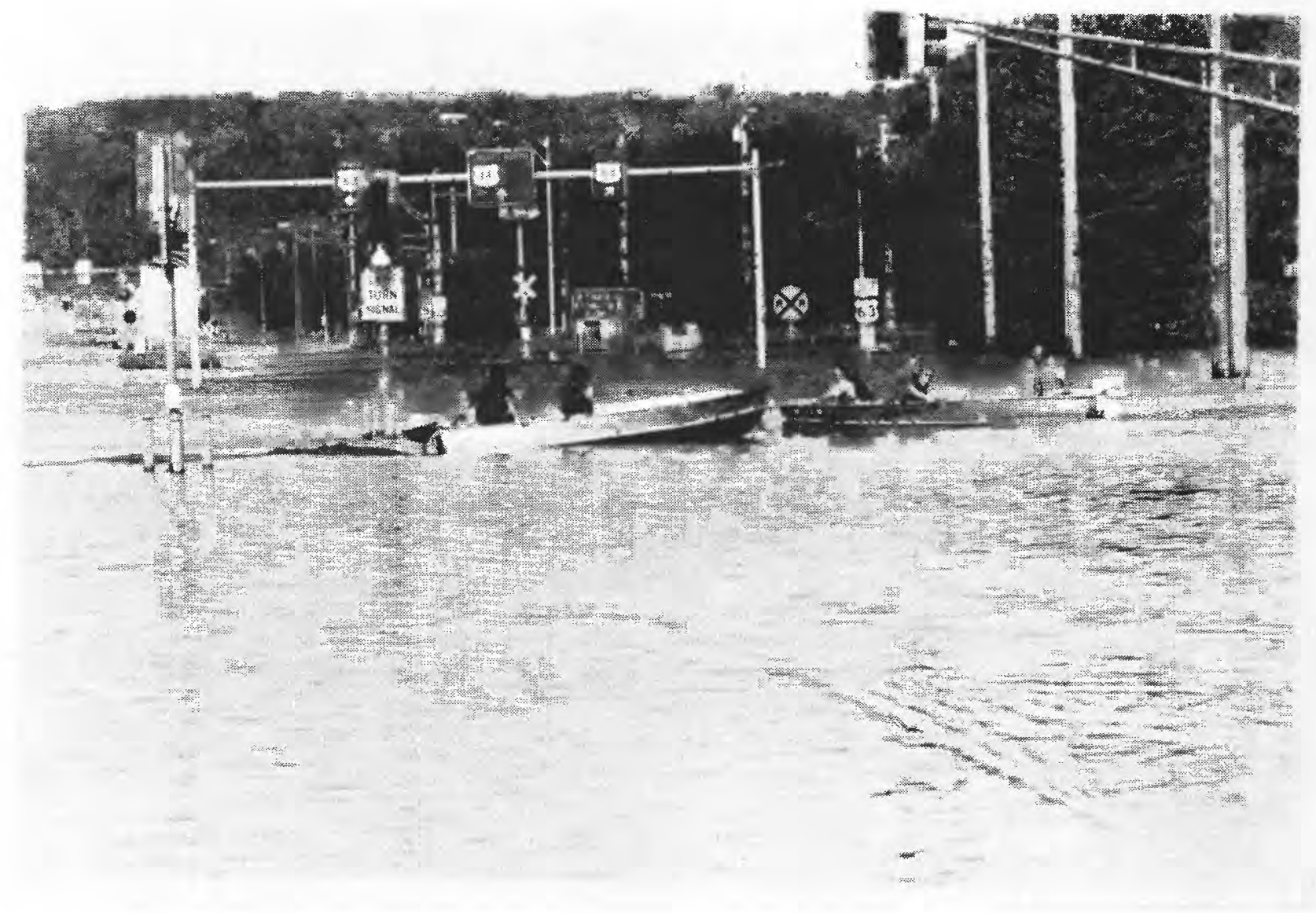

Figure 10.--Third Avenue SE and the BeltIlne, Rochester, MInn. (Rochester Post-Bullet/n, July 6, 1978) 


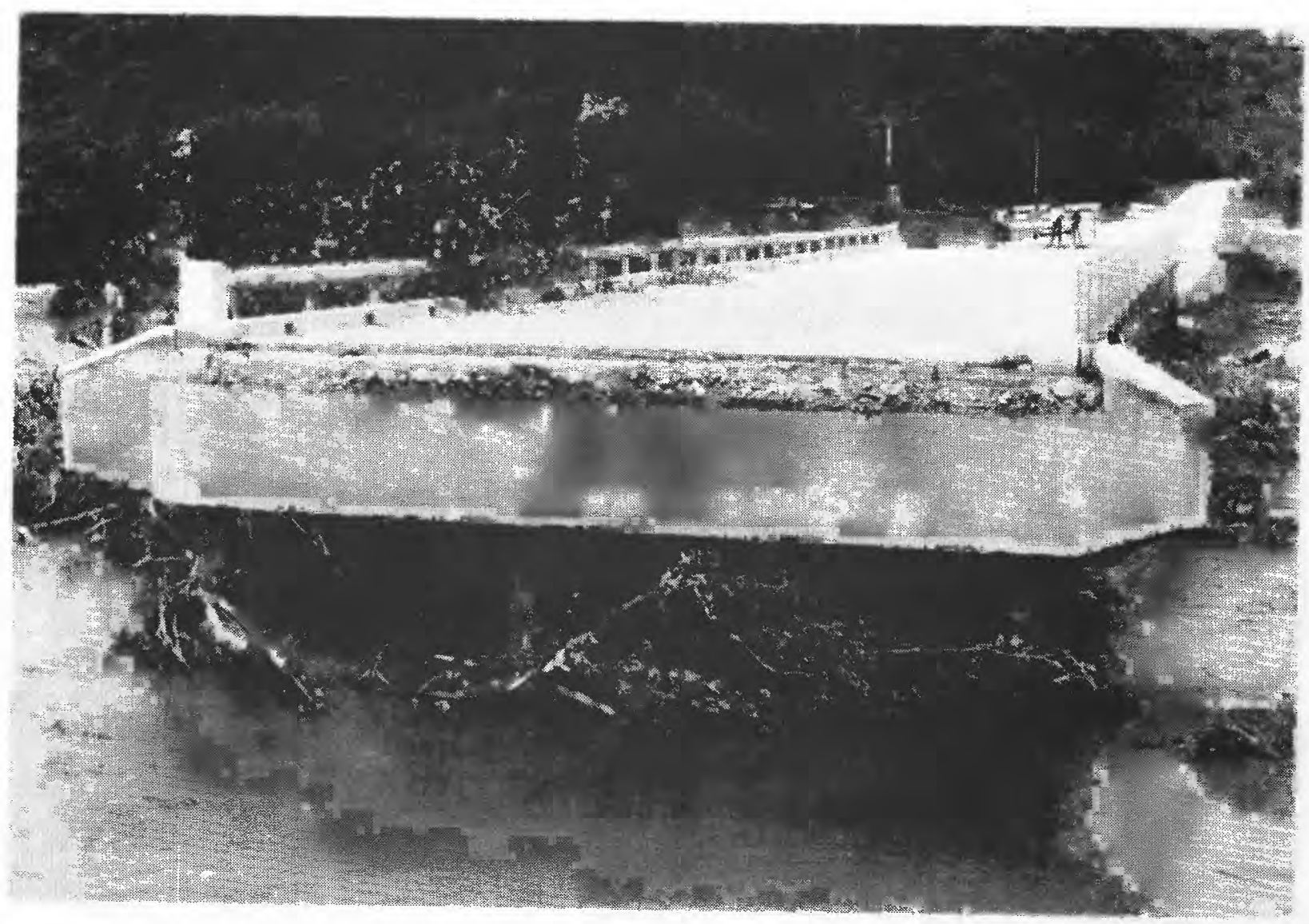

Figure 11.--Winona County Road 39 bridge over the Whitewater River near Whitewater State Park, Minn. (Rochester Post-Bulletin, Juiy 6, 1978) 


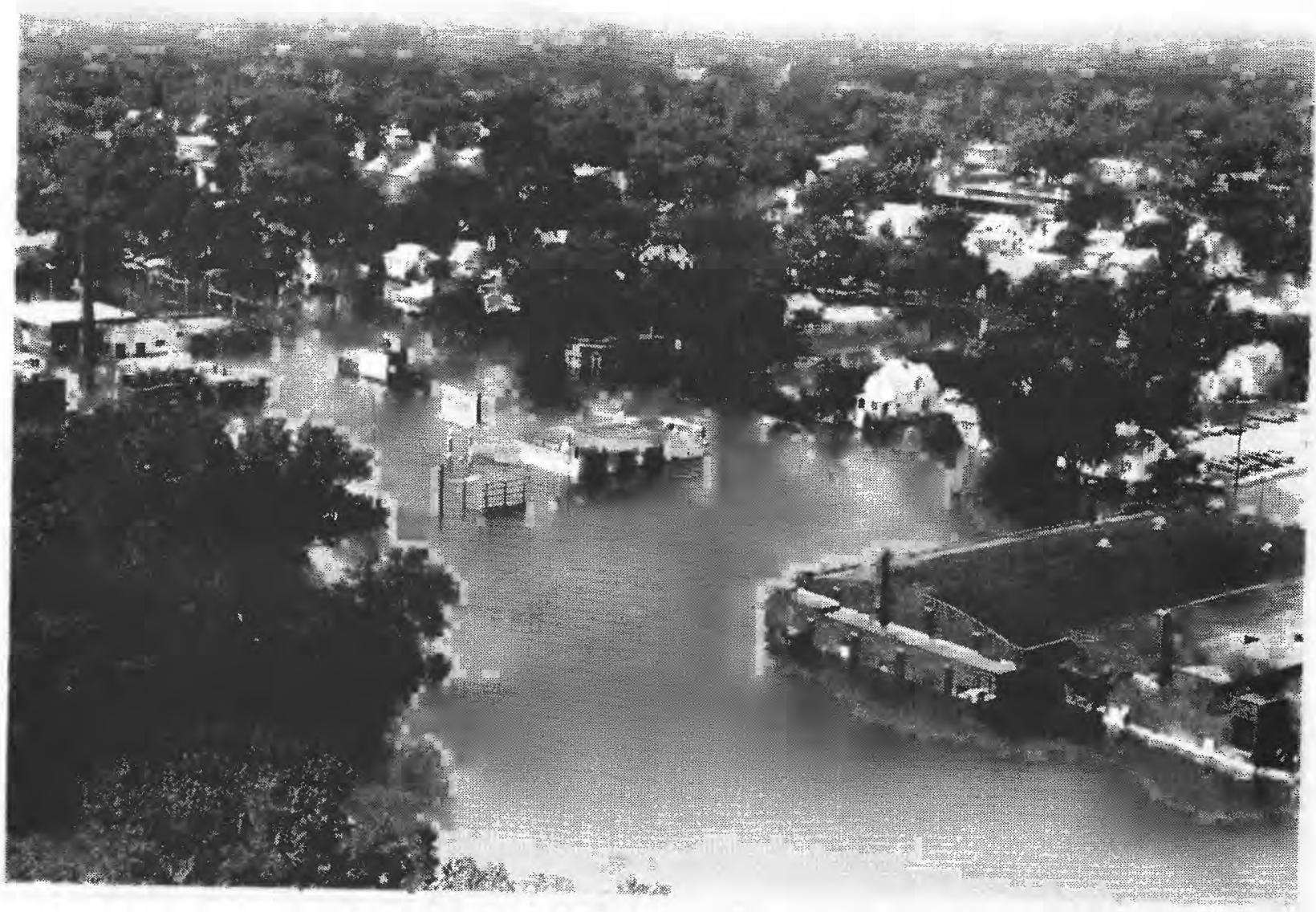

Figure 12.--East Oakland Avenue and 4th Street SE on the Cedar River, Austin, Minn. (Austin Daily Herald, July 17, 1978) 


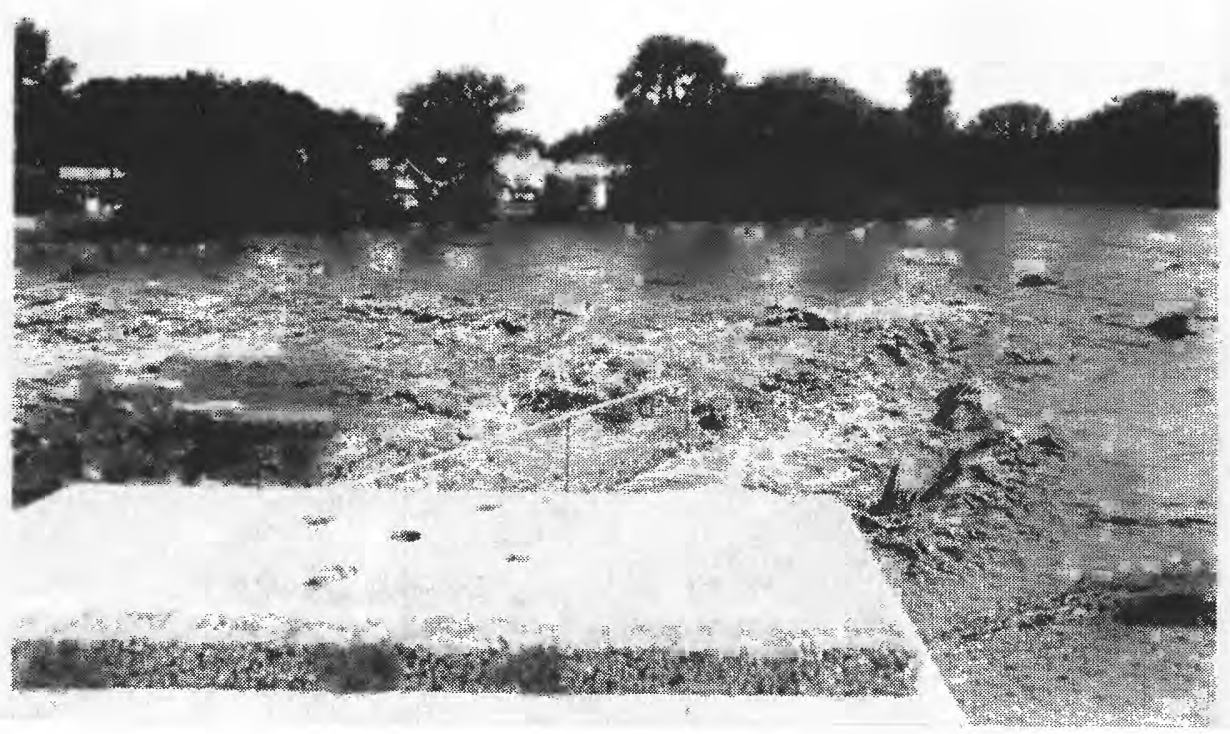

Figure 13.--Cedar River below the 4th Avenue NE bridge, Austin, Minn. (Austin Daily Herald, July 17, 1978) 


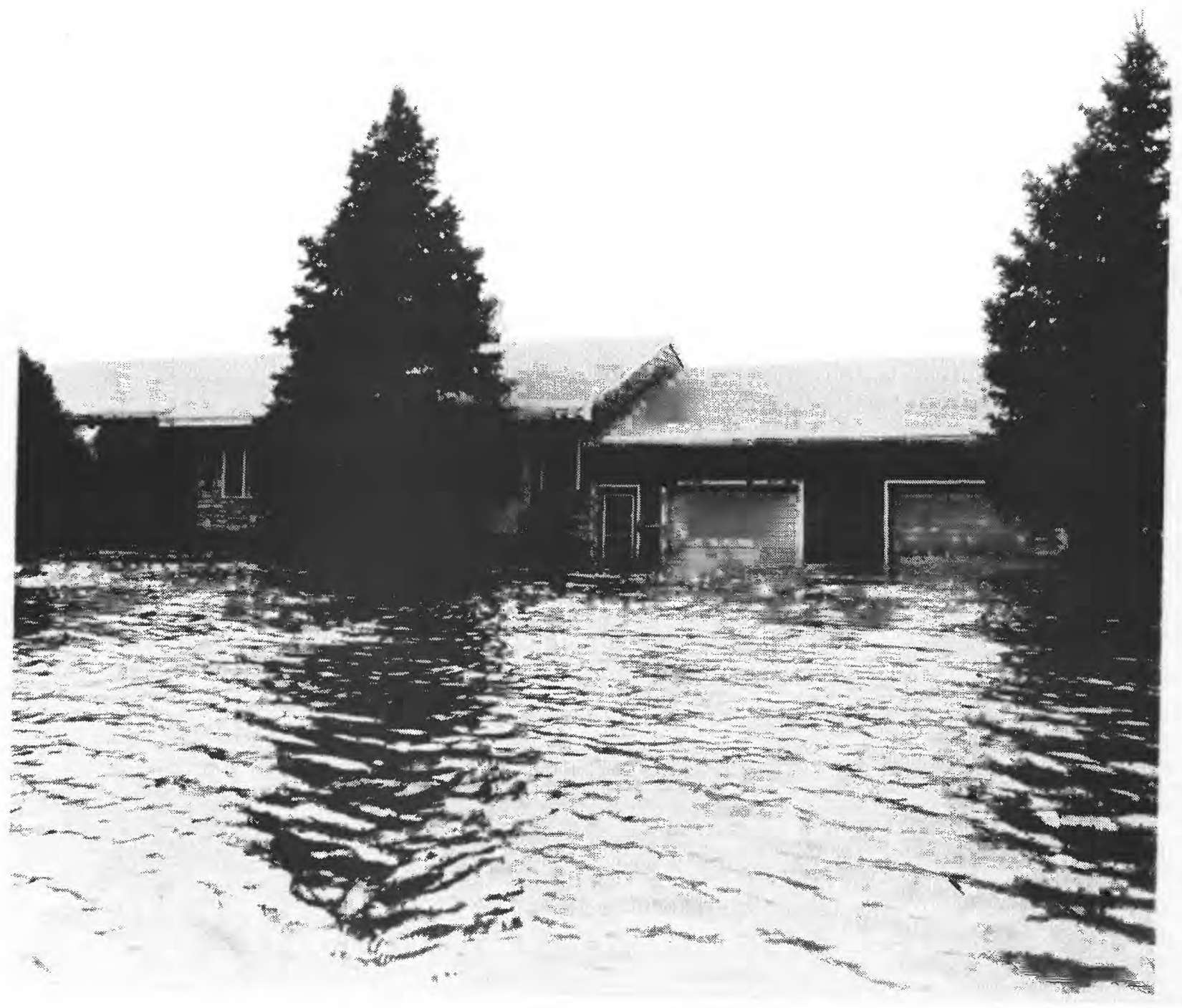

Figure 14.--Flooded home in Wildwood Park, Austin, Minn. (Austin Daily Herald, July 17, 1978) 


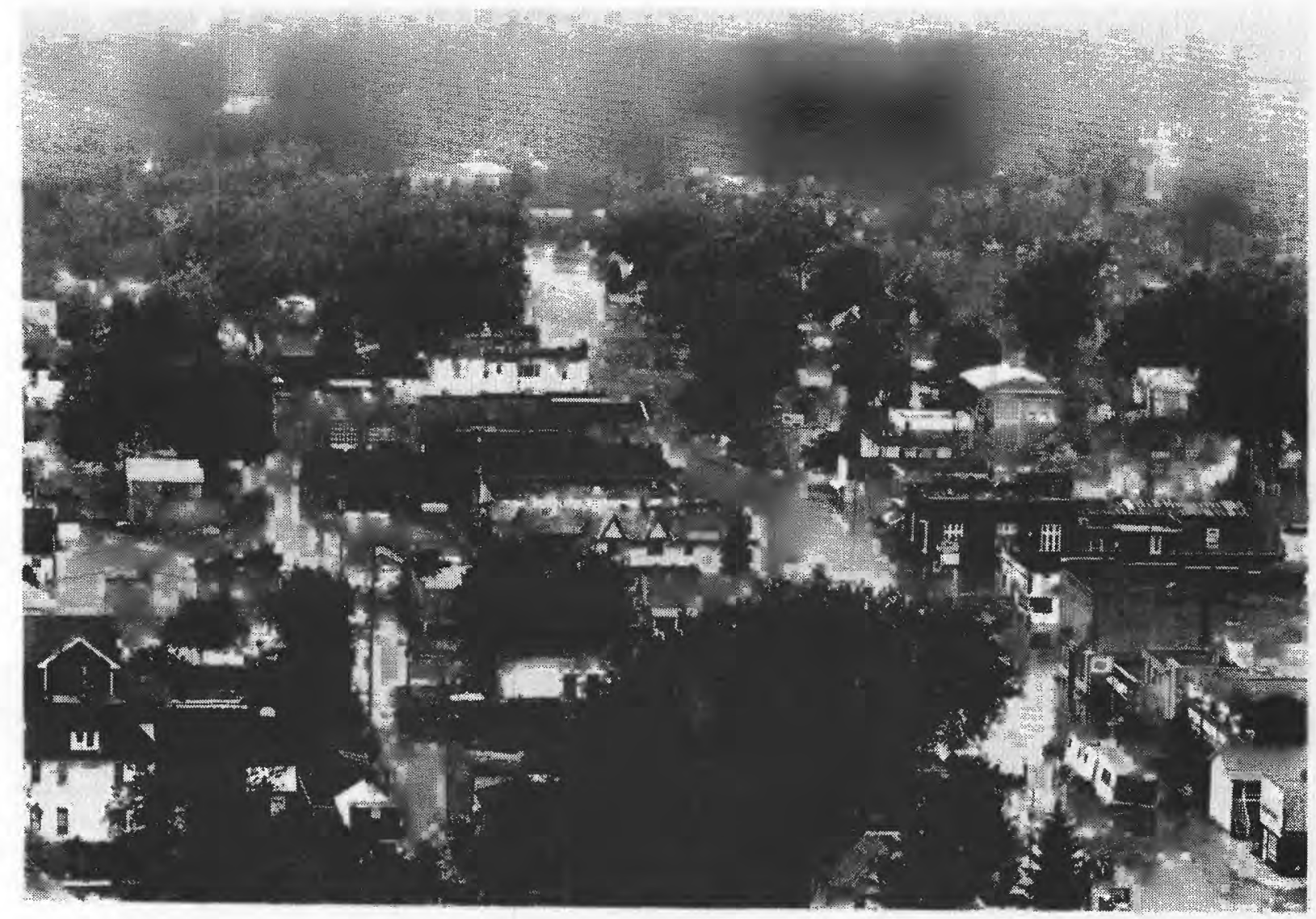

Figure 15.--The Kickapoo River, Gays Mills, Wis., July 1, 1978 (Jorgensen Photo, Gays Mills, Wisc.J 


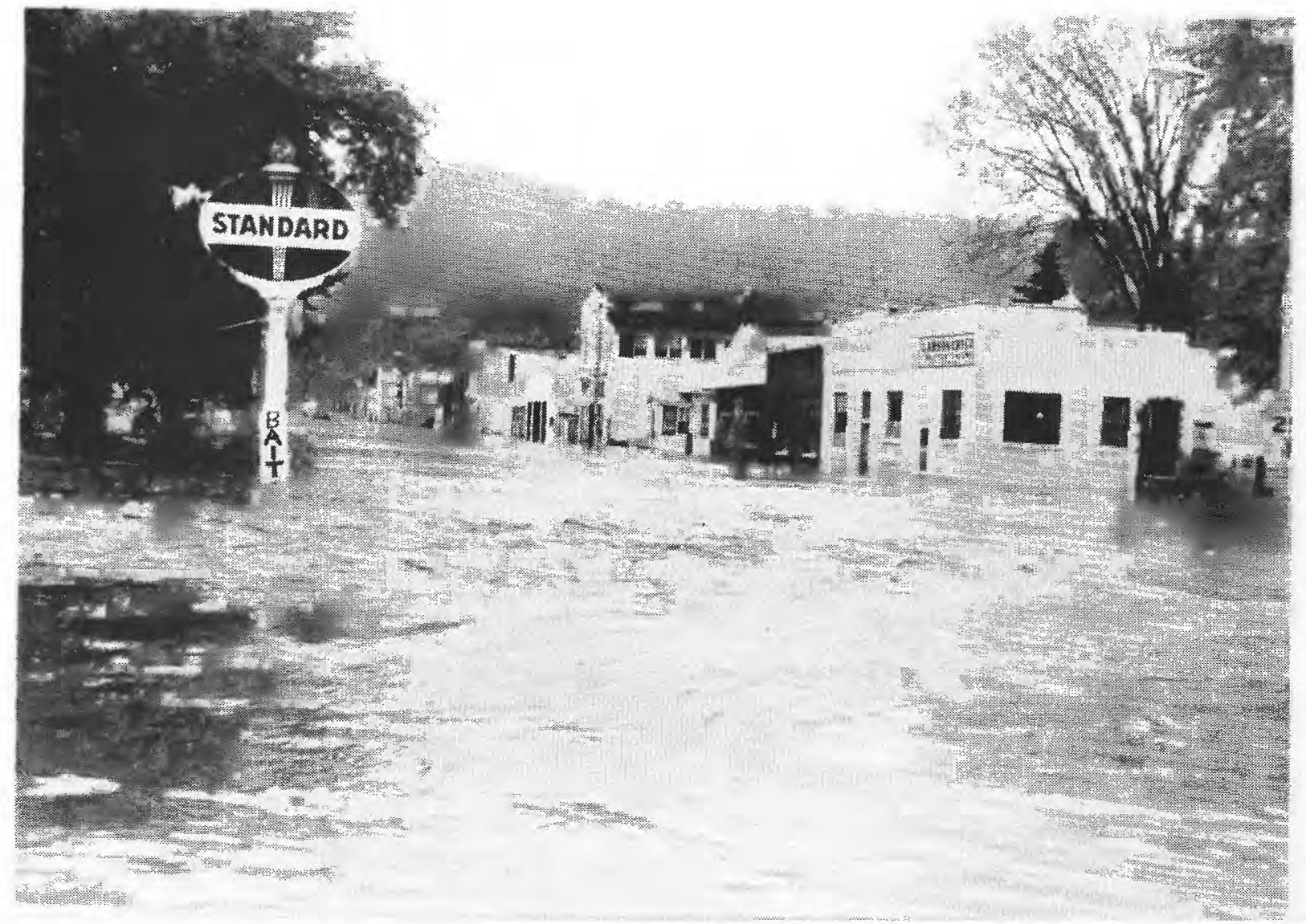

Figure 16.--Main Street, Gays Mills, Wis., July 1, 1978 (Jorgensen Photo, Gays Mills, Wis.) 


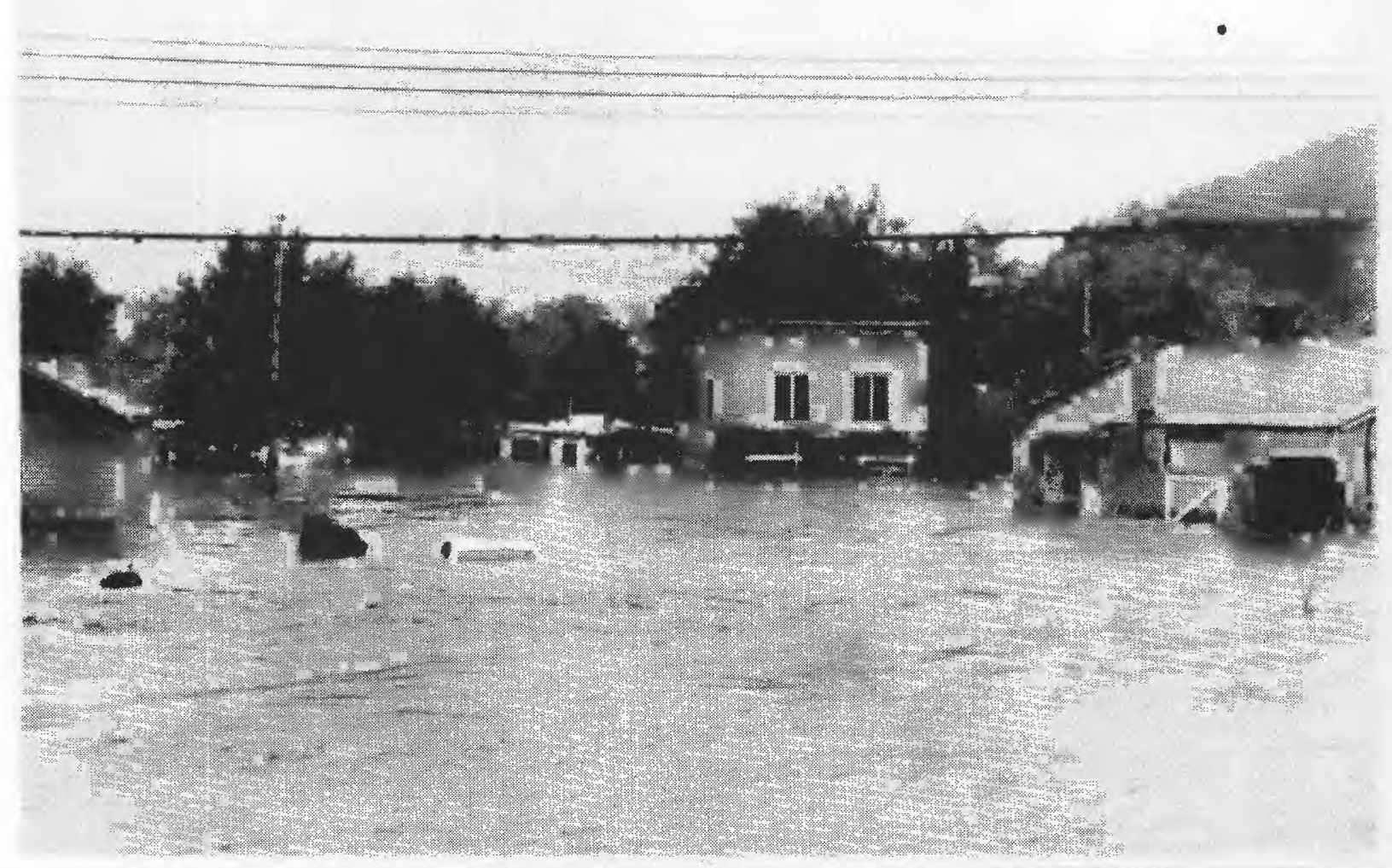

Figure 17.--Kickapoo River, Soldiers Grove, Wis., July 1, 1978 (Boscobel Dial, Boscobel, Wis.) 


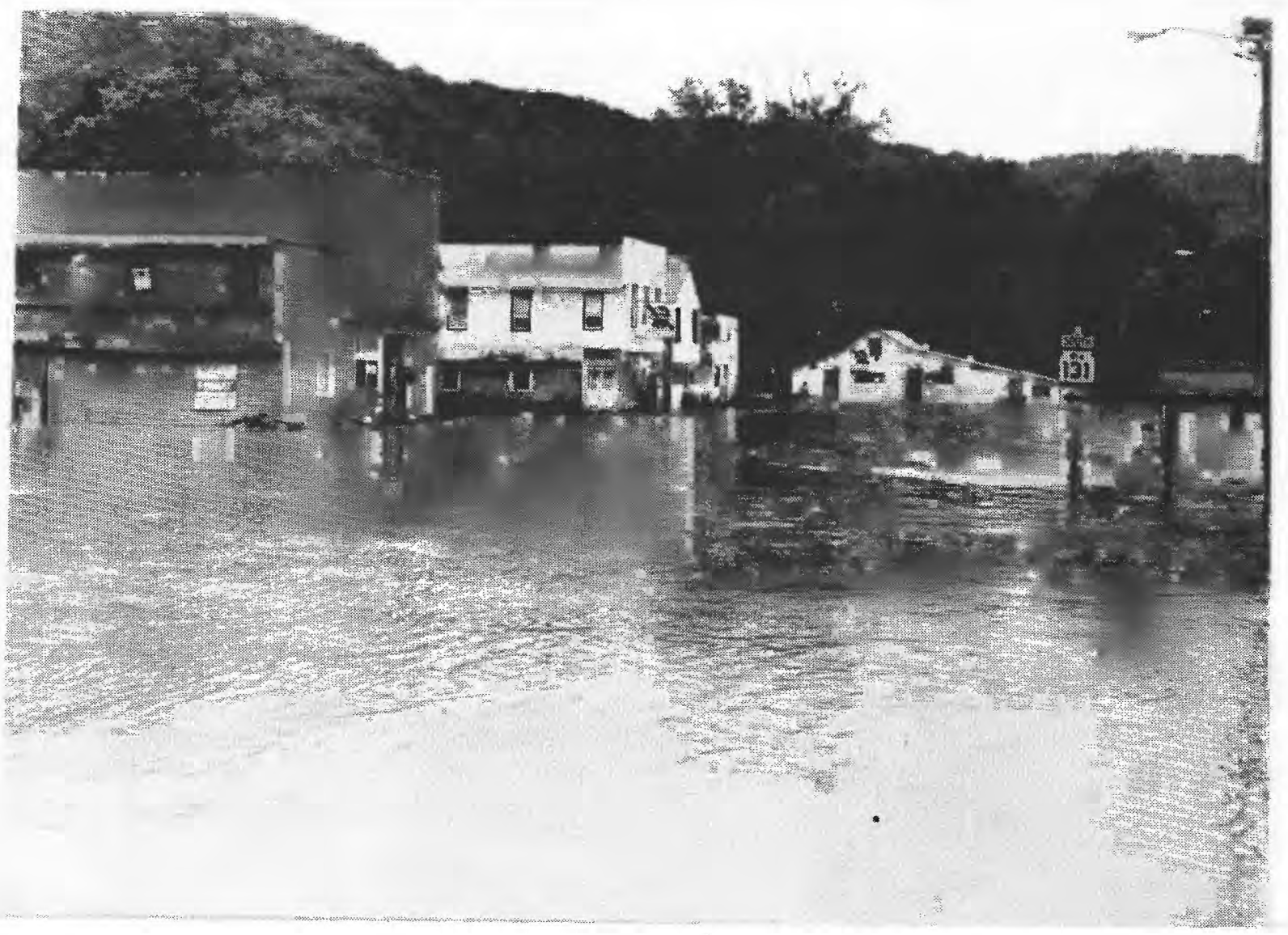

Figure 18.--Kickapoo River, Steuben, Wis., July 1, 1978 (Boscobel Dial, Boscobel, Wis.) 


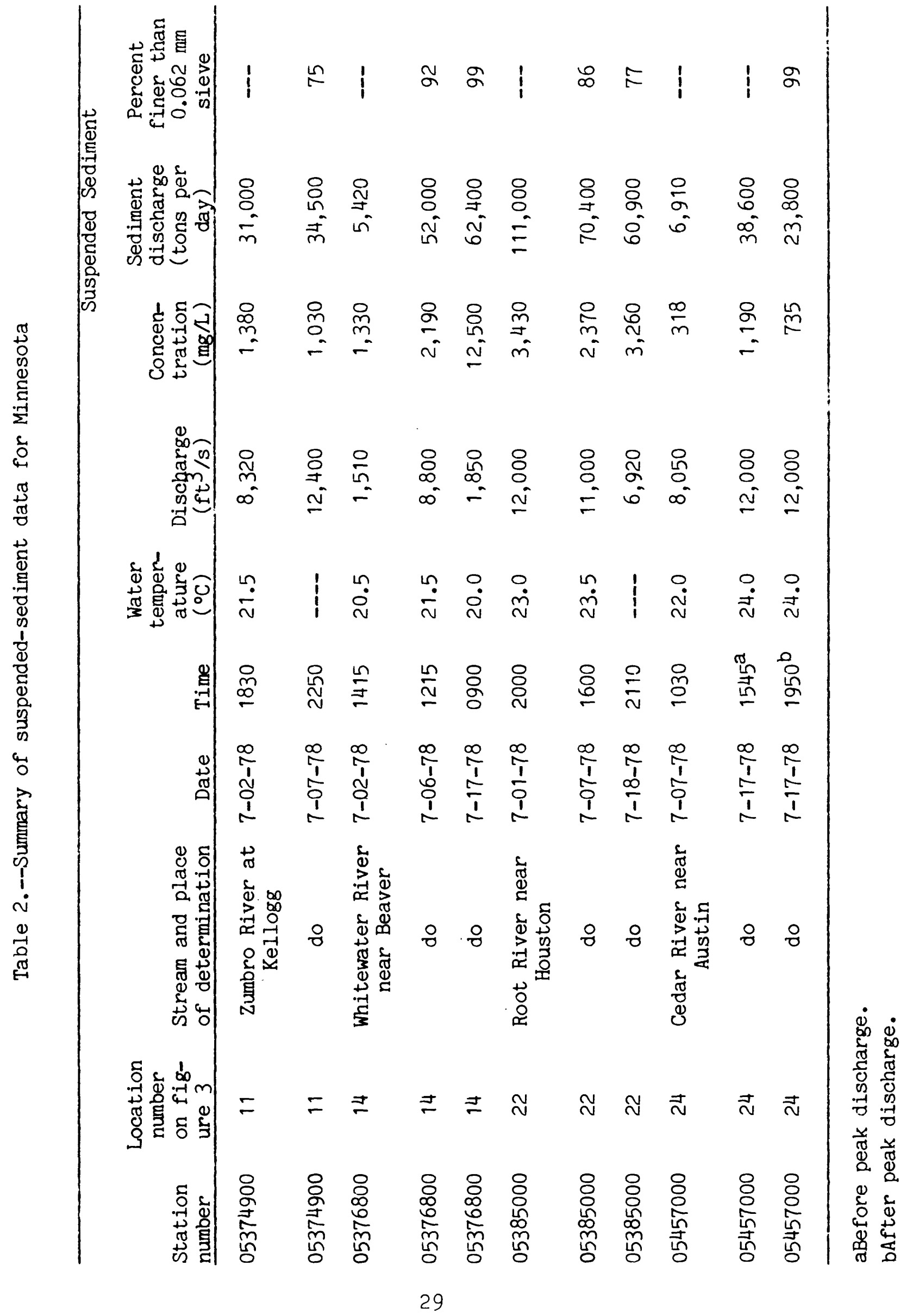


